\title{
FINANCIAL STATEMENT, 1919
}

\author{
RECEIPTS FOR THE YEAR 1919
}

To Balance January 1. $1919 \ldots \ldots \ldots \ldots \ldots \ldots \ldots \ldots \ldots$

To Contributions $\ldots \ldots \ldots \ldots \ldots \ldots \ldots \ldots \ldots \ldots \ldots \ldots \ldots$

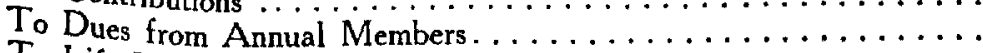

To Life Membership (W. Graham Tyler) . . . . . . . . .

To Income from Investments .............

$\$ 2,089.11$

$3,454.00$

834.00

50.00

To Income from Anna Blanchard Fund.

$2,327.77$

220.50

227.22

50.40

To Income from Henry A. Rogers Fund

139.16

To Income from Isaac Barton Fund (for Tools)

720.00

To Payment from I. V. Williamson Charities..............

To Interest on Deposits

52.20

To Proceeds from Sale of Literature.

To Amount returned by Discharged Prisoners.

58.73

Total Receipts

$\$ 10,230.59$

\section{PAYMENTS IN 1919}

For Aid and Relief of Discharged Prisoners. . . . . . . . . .

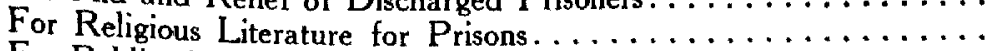

For Publication and Distribution of Annual JournaL. . . . . . .

For Dues to Affiliated Organizations..................

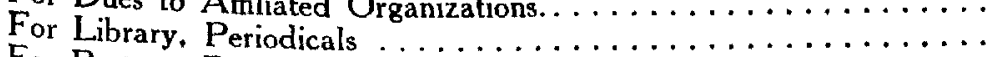

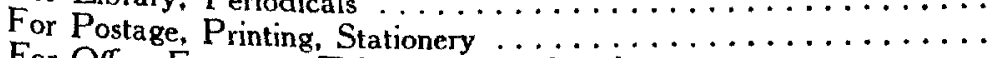

For Office Expenses, Telephone, Incidentals. $\ldots \ldots \ldots \ldots \ldots \ldots \ldots$

For Rent of Office

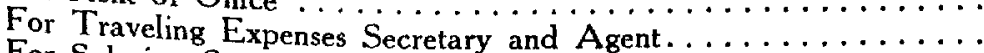

For Salaries, Secretaries, Agent

For Payment to Fiscal A Agent

For Banent to Fiscal Agent for Investment.

Total Payments, Including Balance.

$\$ 10,230.59$

REPORT ON FUNDS HELD FOR HOME OF INDUSTRY

Receipts on Account of Income.

We, the undersigned, members of the Audit Committee, have examined the foregoing account of John Way, Treasurer, compared the payments with the vouchers, and believe the same to be correct.

Philadelphia, January 1, 1920.

WATSON W. DEWEes,
ISAAC P. MiLlER, 